\title{
The Influence of Artist in Schools (AiS) Program and the ARCS Motivational Model on Students' Creativity and Motivation in Visual Art
}

\author{
https://doi.org/10.3991/ijet.v14i20.11464 \\ Wan Juria Emeih Wahed $(\bowtie)$, Abdul Halim bin Husain \\ Sultan Idris Education University, Tanjung Malim, Malaysia \\ juliewahedegmail.com \\ Wan Juliana Emeih Wahed, Patricia Pawa Pitil \\ Universiti Teknologi MARA, Sarawak, Malaysia
}

\begin{abstract}
The word 'education' comes from the Greek word 'educare' which means carrying out the potentials stored in the children's psyche to be guided in order for them to grow. It involves the dissemination of information or knowledge to, and acceptance by, a student which results in the receiver's behavioral changes. The "Artist in Schools" (AiS) program was initiated by the researchers and became the platform for the collaboration between schools and artists aimed at increasing the students' motivation in arts education. It encompasses the sharing of knowledge and experiences between the two groups. This paper is aimed at analyzing the students' creativity and motivation in visual art by using the ARCS Motivational Model. Using the multi-case studies, nine secondary schools from Peninsular Malaysia were selected as the sample of the study. In-depth interviews, observation and analysis of related documents were applied. The data were presented narratively. The result revealed that AiS was significantly functional and instrumental in enhancing and encouraging the level of creativity and motivation of the students in visual arts. This study may give great impact to the students' development specifically in the learning of visual arts.
\end{abstract}

Keywords - Artist in Schools; Collaboration; Motivation; School Students; Visual Arts Education

\section{Introduction}

\subsection{Background}

In general, the achievement of formal education in Malaysian schools is impressively as stated by Ministry of Education Malaysia. However, like many other Southeast Asian countries, there are several challenges and issues that need proper attention in order to compete with the socio-economy globalization [1]. Visual art education in schools seems to be neglected or receives inadequate recognition from the school 
management [2]. This trend can affect the teaching and learning process, the students' creativity and thus the performance of the Malaysian education.

The creative culture and innovation in teaching and learning in schools are still lagging in the Malaysian education system although it is one of most effective approaches to increase imagination skills and creativity to the optimum [3]. The 21stcentury learning process should focus more on the collaborative learning environment, high order thinking and life practicality. However, that 'formula' is still not being applied in the teaching of Visual Art Education or PSV in Malaysia.

Motivational enhancement in the formal art education through artist-school collaboration is a new phenomenon in Malaysia. However, in some other countries, especially in the developed ones, it is an increasingly critical element in the teaching system and school curriculum [4].

\subsection{The artists in schools (AiS) program}

This study aims to explore the creativity and motivation of Malaysian secondary school students in the process of learning visual arts subjects through collaboration between school - artists, in the program entitled as "Artists in Schools" (AiS). AiS is a collaborative effort between schools and artists towards the sharing of experiences and knowledge of the artists with secondary school students. The effectiveness of this program is assessed through its impact on the motivation of the target groups (secondary school students) which in turn is an indication of the increased potential of their creativity.

\subsection{The ARCS motivational model}

ARCS theory is based on the synthesis of concepts and motivational features that are constructed from four categories: Attention (A), Relevance (R), Confidence (C), and Satisfaction (S). These four categories are accepted as conditions that need to be created or produced in a learning process towards ensuring the existence of the target group motivation in the learning process.

\section{Literature Review}

"Art" is a term that has not yet received a universal definition. It may not be defined [7]. Artworks are merged with a "family" equation network, and not by an essential definition [8]. Art is an imitation or presentation [9] while, it as a transference of feeling, [10] and an intuitive expression [11]. In the Universal Theory, art exists in every aspect of human life construction because it is rooted in human needs as well as in relation to the inherent value of belief in his soul [12].

The students' tendency towards visual art education and its work processes will increase if the method used is interesting, relevant, and scientifically valuable [13]. The process of effective motivation enhancement not only helps teachers to assists the students in appropriate methods of learning but also has the potential to produce a 
creative human capital. Understanding the concepts, and skills in art compositions will get better through experience, training, and methods with relevant innovation [14].

\subsection{Student disclosure to the outside world towards motivation improvement}

Motivation is the process that initiates, drives, and maintains goal-oriented behavior [15]. Motivation is what makes you act, whether to take a glass of water to reduce thirst or read a book to acquire knowledge. Over the last 40 years, awareness of the benefits of exposure among students to the environment beyond the school in driving the potential of students have been emphasized through educational psychology. Students will become active when they can connect the new knowledge they learn to the real world [16] [17]. Through this process, students are provided with good composing skills with the help of teachers and experienced artists in the real world and referred to as the source of expertise. This is not surprising: the real world outside the school is a phenomenon that is packed with a variety of views, forms, social patterns, and possibilities.

\subsection{Collaboration and motivation}

Collaboration as direct communication between the two groups who agree to make the decision to achieve the same goals [18]. It is described collaborative from the term of role, relationships, values and ways of working as creative collaboration complemented each other [19]. Collaboration not only means working together but working together to achieve common goals that individuals or organizations alone cannot achieve [20]. Artist collaboration practice can contribute to enhancing creativity and self-expression [22]. These changes begin with the increased motivation of the field. Artists who work together with the community do not just share knowledge and experience about art with others, but also stimulate and motivate the artistic process of community members who may be less exposed to art [23]. Through this collaboration, an artist will encourage and challenge the audience to explore new ways of thinking, feeling, and doing something. It also, indirectly, can enhance the ability to communicate and communicate.

\subsection{Methodology / materials}

This study meets the qualitative research. It focuses on deeply understanding the collaborative impacts between a professional artist and the students in applying art experiences, skills and techniques in art, to explore the level of creativity and motivation of high school students in Visual Art Education or PSV through AiS program. In terms of data collection and theory generation, qualitative research uses many face-toface interaction methods with research subjects and inductive approaches to generate a theory, in addition to using small samples, citing data in focus and depth as well as making narrative narratives and interpretations. 
Nine secondary schools were selected based on the six zones in Peninsular Malaysia namely upper north (Kedah), lower north (Perak), upper east coastal (Kelantan and Pahang), central (Kuala Lumpur), and the west (Melaka) (Table 1). Their selection was made through the list of schools which registered at the AiS program website at http://www.artistsinschoolsmalaysia.com developed by the researcher.

Table 1. Locations, population and study samples of the schools involved in the study

\begin{tabular}{|c|l|l|c|c|}
\hline No & \multicolumn{1}{|c|}{ State } & \multicolumn{1}{|c|}{ Zone } & Population & Study sample \\
\hline 1 & Melaka & West & 19 & 1 \\
\hline 2 & Perak & North & 19 & 1 \\
\hline 3 & Perak & North & 47 & 1 \\
\hline 4 & Perak & North & 39 & 1 \\
\hline 5 & Perak & North & 36 & 1 \\
\hline 6 & Kedah & North & 43 & 1 \\
\hline 7 & Pahang & East & 28 & 1 \\
\hline 8 & Kelantan & East & 34 & 1 \\
\hline 9 & Kuala Lumpur & Central & 32 & 1 \\
\hline \multicolumn{2}{|l}{ TOTAL } & 319 & 9 \\
\hline
\end{tabular}

The triangulation method of in-depth interviews, observations, and the analysis of the relevant documents were adopted to produce the relevant data to the study. Indepth interviews with one students' representing each school were held and researchers acted as facilitators to ensure students understand the content of the questions raised (Table 2). These in-depth interviews are aimed at understanding the students' perceptions of the AiS program in depth.

Table 2. The questions posed to the students after each AiS session

\begin{tabular}{|l|l|}
\hline \multicolumn{1}{|c|}{ ARCS component } & \multicolumn{1}{c|}{ Question } \\
\hline Attention $(\mathrm{A})$ & 1. What is your view towards the guest artist? \\
\hline Relevance $(\mathrm{R})$ & 2. What are the things you find important or relevant to you? \\
\hline Confidence (C) and Satisfaction $(\mathrm{S})$ & 3. Is the program interesting or appealing to you? \\
\hline
\end{tabular}

\subsection{Result and findings}

Responses: This subsection highlights selected responses from the students to illustrate their views on the program. The responses are categorized into the four ARCS components to illustrate the presence of each component in the responses.

\section{Attention}

- "The artist is a very relaxed and simple person. His delivery was clear and easily understood."

- "So exciting! Because I had never seen an artist in real life before this."

- "This is what I want!"

- "I obtained knowledge which I don't get from the teachers at school."

\section{Relevance}


- "I learned on how to make creative and attractive posters."

- "This is what I want after all this time. This collaboration is advantageous to me."

- "I gained a lot of things from this program even though it seemed very brief. I also understand the importance of creativity stressed by the artist and I learned a lot while interacting with the artist and there are a lot things I gain from this program."

- "I want this program to be continued so that the students will understand other techniques in drawing and painting."

- "In this program, we received a lot of exposure on visual arts, and know how to draw and paint."

\section{Confidence}

- "His delivery made it easy for me to understand the subject."

- "I believe I can think creatively using the basic materials given to me."

- "The artist taught me to be brave in exploiting the colors".

- "The artist encouraged freedom in drawing especially in the usage of materials, for example, in minimizing the use of pencils. I am exposed to new opportunities and can improve my creativity potential in arts."

\section{Satisfaction}

- "Exciting! Because I learned new things and had an interesting experience."

- "This program is satisfying because we can meet up with an artist who is very famous and we learned new skills in drawing."

- "In this program, a lot of people can help us to improve ourselves in arts. Apart from that, we can enhance our potentials in arts."

- "This program should be continued. Maybe the school doesn't see arts education as important. The fact is, it is very important in building students' personalities and spiritual aspects compared to science and mathematics."

- "It should be continued because it has a lot of benefits to the PSV students."

Observation: Table 3 shows the observations made on each informant. Notes were made on the most visible behaviors or acts of the informant which can be translated into the four ARCS components. Only the positive behaviors are indicated since they reflect the presence of the four components.

Table 3. Observations made on each informant during the AiS sessions

\begin{tabular}{|c|l|c|c|c|c|}
\hline \multirow{2}{*}{ Informant } & \multicolumn{4}{c|}{ The relevant ARCS component } \\
\cline { 3 - 6 } & & $\boldsymbol{A}$ & $\boldsymbol{R}$ & \multicolumn{1}{c|}{$\boldsymbol{C}$} & \multicolumn{1}{c|}{$\boldsymbol{S}$} \\
\hline (M) A: & Attentive & $\mathrm{X}$ & $\mathrm{X}$ & & \\
\hline \multirow{2}{*}{$(\mathrm{M}) \mathrm{B}:$} & Attentive & $\mathrm{X}$ & $\mathrm{X}$ & & \\
\cline { 2 - 6 } & Competitive & & & $\mathrm{X}$ & \\
\hline \multirow{2}{*}{$(\mathrm{M}) \mathrm{C}:$} & Sketching in notebook & $\mathrm{X}$ & & & \\
\cline { 2 - 6 } & Inquisitive & $\mathrm{X}$ & $\mathrm{X}$ & & \\
\hline \multirow{2}{*}{$(\mathrm{M}) \mathrm{D}:$} & Inquisitive & $\mathrm{X}$ & $\mathrm{X}$ & & \\
\hline & Interested with artwork & $\mathrm{X}$ & $\mathrm{X}$ & & \\
\hline$(\mathrm{M}) \mathrm{E}:$ & Attentive & $\mathrm{X}$ & $\mathrm{X}$ & & \\
\hline
\end{tabular}




\begin{tabular}{|c|l|c|c|c|c|}
\hline & Making notes & $\mathrm{X}$ & & & \\
\hline \multirow{3}{*}{$(\mathrm{M}) \mathrm{F}:$} & Attentive & $\mathrm{X}$ & $\mathrm{X}$ & & \\
\cline { 2 - 6 } & Nodding several times & $\mathrm{X}$ & $\mathrm{X}$ & & $\mathrm{X}$ \\
\hline & Inquisitive & $\mathrm{X}$ & $\mathrm{X}$ & & \\
\hline & Active in answering artist's questions & & & $\mathrm{X}$ & \\
\hline \multirow{3}{*}{$(\mathrm{M}) \mathrm{G}$} & Attentive & $\mathrm{X}$ & $\mathrm{X}$ & & \\
\cline { 2 - 6 } & Writing down notes & $\mathrm{X}$ & $\mathrm{X}$ & & \\
\cline { 2 - 6 } & Focused & $\mathrm{X}$ & $\mathrm{X}$ & & \\
\hline \multirow{2}{*}{$(\mathrm{M}) \mathrm{H}$} & Attentive & $\mathrm{X}$ & $\mathrm{X}$ & & \\
\cline { 2 - 6 } & Nodding head & $\mathrm{X}$ & $\mathrm{X}$ & & $\mathrm{X}$ \\
\hline \multirow{3}{*}{$(\mathrm{M}) \mathrm{I}$} & Hardworking & $\mathrm{X}$ & $\mathrm{X}$ & & \\
\cline { 2 - 6 } & Attentive & $\mathrm{X}$ & $\mathrm{X}$ & & \\
\cline { 2 - 6 } & Taking notes & $\mathrm{X}$ & $\mathrm{X}$ & & \\
\cline { 2 - 6 } & Inquisitive & & & \\
\hline
\end{tabular}

\subsection{Conclusion}

Looking from the point of view of the ARCS theory, both categories of feedbacks - verbal and behavioral - revealed the presence of the motivation among the informants participating in the AiS program. Although the components were easily and clearly detected under the response category, they are not so under the behavioral observation. This is particularly true for the Confidence and Satisfaction components. This may be due to the fact that those emotions are seldom clearly visible, even if they do exist.

Based on the verbal responses, many students were seen as motivated due the fact that the program had exposed them to a lot of new knowledge and skills brought by the artists. As a result of this, the students will become more self-efficacious and thus more motivated [24] [25].

Being at a "rebellious" age, this motivation was also a product of the artists' encouragement to be artistically free and daring. Having professional artists to come at their schools was definitely a strong element of surprise which caught the attention of the students. Some of the students felt this new way of teaching as a refreshing experience and more exciting than the routine of the PSV classes.

Every informant showed at least one positive sign of behavior indicating the one or more of the ARCS components. The main indications were attentiveness, and notewriting or doing sketches. These signs were mostly indicative of the Attention and Relevance components.

Such responses are parallel to the findings of [26], [27] and [28] that the way the classrooms are being structured will determine the degree of conduciveness and facilitative of the learning process towards enhancing the students' motivation and engagement toward learning activities. In line with the presence of the artists who were seen by the students as more experienced and well-versed in their profession, [26], in his study with Al-Ain University students, finds that teacher's personal quality from students perspective is the most vital factor that determines the students' learning motivation. This view is also supported by previous studies [29], [30] and [31]. 


\section{Acknowledgement}

The authors deeply thank all the respondents for their kind participation and their positive feedback.

\section{References}

[1] Sadiman, A. S. (2004). Paper presented at the International Seminar on "Towards Cross Border Cooperation between South and Southeast Asia: The Importance of India's North East Playing Bridge and Buffer Role”, Kaziranga, India, 16-19 November 2004.

[2] Ling, P. K., Sharifah N. P. \& Hasnah, T. (2014). Pembinaan dan pelaksanaan modul aktiviti seni kreatif (dalam bidang seni visual) untuk pendidikan prasekolah. $\mathrm{PhD}$ thesis, Universiti Kebangsaan Malaysia.

[3] Mohd. Azhar A. H. (2001). Pengenalan Pemikiran Kritis dan Kreatif. Skudai: Universiti Teknologi Malaysia.

[4] Irwin, R. L. (2004). An artful curriculum/ A curriculum full of life. In Kevin D. Vinson \& E. Wayne Ross (Eds.). Defending public schools. Volume Three: Curriculum continuity and change in the 21 st century (pp. 3-15). Westport, CT: Praeger.

[5] Keller, J. (2000). How to integrate learner motivation planning into lesson planning: The ARCS model approach. Paper presented at VII Semanario, Santiago, Cuba, February, 2000

[6] Davies, S. (2013). Routledge Companion to Aesthetics, Berys Gaut \& Dominic McIver Lopes (eds), (London: Routledge, 2013, 3rd edition)

[7] Weitz, M. (1956). The Role of Theory in Aesthetics. Journal of Aesthetics and Art Criticism 15: 27-35.

[8] Plato (1955). Republic, trans. H. D. R Lee, London: Penguin

[9] Tolstoy, L. (1995). What Is Art? trans A. Maude, Oxford: Oxford University Press.

[10] Croce, B. (1920) Aesthetics, trans. D. Ainslie, London: Macmillan

[11] Siti Zainon, I. (1985). Jalur dan Warna. Kuala Lumpur: Fajar Bakti.

[12] Yudhistira, Siska Y. M. (2012). Pendidikan Karakter dengan Metode Sentral. Jakarta: Media Pustaka Sentra.

[13] Iberahim, H. (2010). Pendidikan Seni : Suatu Pemikiran Semula dalam Kumpulan Esei Pilihan Pendidikan Seni dan Muzik. Universiti Pendidikan Sultan Idris : Tanjong Malim. https://doi.org/10.30880/jts.2019.11.01.004

[14] Cherry, K. (2010). The Everything Psychology Book. Edisi kedua. MA: Adams Media

[15] Piaget, J. (1974). Adaptation and intelligence: Organic selection and phenocopy. Chicago: University of Chicago Press.

[16] Vygotsky, L. S. (1962). Thought and language. NY: John Wiley.

[17] Cook, L. \& Marilyn. (2010). The state of the art of collaboration on behalf of students with disabilities. Journal of Educational and Psychological Consultation, 20:1, 1-8. https://doi. org/10.1080/10474410903535398

[18] John-Steiner, V. (2000). Creative Collaboration. Oxford University Press

[19] Kagan, S. L. (1991). United we stand: Collaboration for child care and early education services. New York: Teachers College Press.

[20] Bamford, A. (2006). The Wow Factor: Global Research compendium on the Impact of the Arts in Education, Waxmann, Germany.

[21] ARVI. (2013). Making Art with Communities. Arts Victoria. Victoria, Australia. 
[22] Fu, J. (2011). The relationships among self-efficacy, achievement motivation, and work values for regular four-year university students and community college students in China. ProQuest Dissertations and Theses, 187.

[23] Mills, N. A. (2004). Self-efficacy of college intermediate French students: Relation to motivation, achievement, and proficiency. ProQuest Dissertations and Theses, 137.

[24] Halawah, I. (2011). Factors influencing college studentse motivation to learn from students" perspective. Education, 132(2), 379-390.

[25] Irvin, J.L., Meltzer, J. \& Dukes, M. S. (2007). Student motivation, engagement, and achievement. Retrieved March 8, 2014, from http://www.ascd.org/publications/books/ 107034/chapters/Student-Motivation,-Engagement-and-Achievement.aspx.

[26] Williams, K. C., \& Williams, C. C. (2011). Five key ingredients for improving student motivation. Research in Higher Education Journal, 12, 1-23.

[27] Chang, I. Y., \& Chang, W.Y. (2012). The effect of student learning motivation on learning satisfaction. International Journal of Organizational Innovation(Online), 4(3), 281-305.

[28] Zou, A., \& Liang, A. (2006). Learners' motivation and the implications for classroom Teaching. Canadian Social Science, 2(3), 59-62.

[29] Mokhtar, S.F., Md Yusof, Z. \& Misiran, M. (2012). Factors affecting students' performance in mathematics. Journal of Applied Sciences Research, 8(8), 4133-4137

\section{$5 \quad$ Authors}

Wan Juria Emeih Wahed is enthusiastically passionate about Visual Art and Culture and actively participate in conferences; locally and internationally.

Wan Juliana Emeih Wahed is an Art Historian and Art Educator, and Senior Lecturer at Universiti Teknologi MARA Kampus Samarahan, Cawangan Sarawak, Malaysia.

Abdul Halim b. Husain is Malaysian expert in Art and Culture study and Senior Lecturer from Sultan Idris Education University, Tanjung Malim, Perak, Malaysia.

Patricia Pawa Pitil is a Sports Science Lecturer at Universiti Teknologi MARA, Kmpus Samarahan, Cawangan Sarawak, Malaysia. She is an active researcher and very interested in cross-disciplined studies.

Article submitted 2019-08-06. Resubmitted 2019-08-29. Final acceptance 2019-09-02. Final version published as submitted by the authors. 